
\title{
Difficulties and facilities pointed out by nurses of a univer-
sity hospital when applying the nursing process*
}

\author{
Dificuldades e facilidades apontadas por enfermeiras de um hospital de ensino na execução do \\ processo de enfermagem \\ Dificultades y facilidades relatadas por enfermeras de un hospital de enseñanza, en la ejecución del \\ proceso de enfermería
}

\section{Alda Akie Takahashi', Alba Lúcia Bottura Leite de Barros², Jeanne Liliane Marlene Michel $^{3}$, Mariana Fernandes de Souza ${ }^{4}$}

\begin{abstract}
Objective: To identify the difficult and easy aspects of performing the different stages of the nursing process, according to the reports of nurses working at Hospital São Paulo. Methods: Eighty-three nurses from 20 different hospital units, where the nursing process was regularly implemented, answered structured research questionnaires. Results: Nursing diagnosis and evolution were the phases where nurses reported more difficulties. Most of the difficult and easy points reported are related to the nurses' theoretical and practical knowledge to perform the phases of the process. Conclusion: Insufficient knowledge becomes an obstacle for the nurses' compliance to the nursing process. An evaluation of theoretical and practical teaching of the nursing process during undergraduate courses is recommended, as well as continuous education in hospital settings.
\end{abstract}

Keywords: Nursing process; Nursing care; Health knowledge, attitudes, practice; Questionnaires

\section{RESUMO}

Objetivo: Identificar as dificuldades e facilidades mencionadas por enfermeiras do Hospital São Paulo na execução das fases do processo de enfermagem. Métodos: Foram entrevistadas 83 enfermeiras, atuantes em 20 unidades de internaçaõ que possuem o processo de enfermagem implantado no serviço, utilizando-se questionários estruturados. Resultados: O diagnóstico e evolução de enfermagem foram as fases que as enfermeiras referiram ter maior dificuldade para operacionalizar. O núcleo das dificuldades e facilidades está relacionado com o nível de conhecimento teórico e prático das enfermeiras para a execução das fases do processo de enfermagem. Conclusão: A falta de conhecimento suficiente torna-se uma barreira para a adesão das enfermeiras ao método. Sugere-se a avaliação do ensino teórico e prático do processo de enfermagem na graduação e a educação permanente nos serviços hospitalares.

Descritores: Processos de enfermagem; Cuidados de enfermagem; Conhecimentos, atitudes e prática em saúde; Questionários

\section{RESUMEN}

Objetivo: Identificar las dificultades y facilidades mencionadas por enfermeras del Hospital Sao Paulo en la ejecución de las fases del proceso de enfermería. Métodos: Fueron entrevistadas 83 enfermeras, que trabajaban en 20 unidades de internamiento que poseen el proceso de enfermería implantado en el servicio, utilizándose cuestionarios estructurados. Resultados: El diagnóstico y evolución de enfermería fueron las fases que las enfermeras refirieron tener mayor dificultad para operacionalizar. El núcleo de las dificultades y facilidades está relacionado con el nivel de conocimiento teórico y práctico de las enfermeras para la ejecución de las fases del proceso de enfermería. Conclusión: La falta de conocimiento suficiente se vuelve una barrera para la adhesión de las enfermeras al método. Se sugiere la evaluación de la enseñanza teórica y práctica del proceso de enfermería en el pregrado y la educación permanente en los servicios hospitalarios.

Descriptores: Procesos de enfermería, Cuidados de enfermería; Conocimientos, actitudes y práctica en salud; Cuestionarios

\footnotetext{
* Excerpt from a Masters Thesis presented to the Nursing Department of the Universidade Federal de São Paulo - UNIFESP - São Paulo (SP), Brazil.

${ }^{1}$ MSc, Professor in the Nursing Undergraduate Course of the Centro Universitário São Camilo - São Paulo (SP), Brazil; RN of the Health Ministry National Health Surveillance Agency - São Paulo (SP), Brazil.

${ }^{2}$ PhD, Full Professor of the Nursing Department of the Universidade Federal de São Paulo - UNIFESP - São Paulo (SP), Brazil.

${ }^{3}$ PhD, Adjunct Professor of the Nursing Department of the Universidade Federal de São Paulo - UNIFESP - São Paulo (SP), Brazil.

${ }^{4}$ Free-Lecturer, Full Professor of the Nursing Department of the Universidade Federal de São Paulo - UNIFESP - São Paulo (SP), Brazil.
} 


\section{INTRODUCTION}

Nurses in health institutions have been using the nursing process as a work method to plan therapeutic actions, thus aiming towards the systematization of nursing care (SNC).

Studies reporting SNC experiences ${ }^{(1-2)}$ mention the difficulties found for its implementation, but they point that a greater challenge lies in maintaining it as a natural process.

These difficulties have also been observed in the professional experience of the first author of this study, when the SNC was being implemented in a public hospital in the 1990s. The author noticed that the success of the systematization was linked to the adoption of a working process and the aggregation of specific variables. These variables comprise: procedural working reforms, redefinition of conceptual and behavioral values of the actors taking part in the scenario where the process occurred, activity delimitation. Consequently, success is also associated with the roles played in the organization, specific scientific knowledge, and infrastructural reformulation of the service.

Barros $^{(3)}$ reports a similar reality and observes that, although all the aforementioned organizational measures had been implemented, the nurses' difficulties to execute the nursing process implanted in the institution remained for all professionals, continuously.

Considering these questions, the development of a study was necessary; one that could make possible to find answers to the following questions:

- Why has it been difficult to implement the process of systematization of nursing care in hospital units?

- Why is the nursing process not designed as the nurse's main activity in the daily professional practice?

A research was performed based on these inquiries, aiming to identify difficult points and easy points described by the nurses of Hospital São Paulo (HSP) to carry out the phases of the nursing process in their workplace.

The health care model adopted in the nursing service of HSP $^{(3)}$ was based on Horta's, Orem's, biomedical and epidemiological conceptual risk models. The nursing process adopted in the HSP is composed of five phases: data collection or nursing history; nursing diagnosis; care planning; implementation or prescription; and nursing evaluation or evolution. To elaborate the nursing diagnosis, the North American Nursing Diagnosis Association (NANDA) taxonomy was used.

\section{METHODS}

The descriptive/exploratory study was approved by the Research Ethics Committee of the Federal University of São Paulo (UNIFESP). The study was performed at
HSP, the university hospital belonging to that institution, in September/2000. The population consisted of 111 active nurses in 20 hospitalization units, and the sample comprehended 83 nurses $(74.7 \%)$ who agreed to participate in this study and signed the consent term.

Data were collected by the first author of this study, respecting Resolution \#196/96 of the Ministry of Health, which regulates research involving human beings. Two questionnaires were used in the study, totaling 26 questions (both structured and open-ended) elaborated from theoretical references about the systematization of care and nursing diagnosis of the NANDA, models of care and brochures adopted at HSP.

The data were entered in an electronic database, using Microsoft Excel @ 2000 spreadsheets. No questionnaire was lost, and statistical analysis of the data coming from structured questions was performed using absolute and relative distribution of variables. Data from the openended questions were analyzed according to content and grouped according to their affinity.

\section{RESULTS}

Table 1 shows that $58.5 \%$ of nurses reported they experienced difficulties when performing nursing diagnosis; $34.2 \%$ faced difficulties with nursing evolution; $32.0 \%$ with care planning, $28.7 \%$ with data collection, and $23.2 \%$ mentioned difficulties with nursing prescription.

Table 1 - Phases of the nursing process nurses find difficult to perform - Hospital São Paulo, 2000

\begin{tabular}{lccccccc}
\hline \multirow{2}{*}{$\begin{array}{l}\text { Phases of the nursing } \\
\text { process }\end{array}$} & \multicolumn{4}{c}{ Yes } & \multicolumn{2}{c}{ No } & \multicolumn{2}{c}{ Total } \\
\cline { 2 - 8 } & $\mathbf{n}$ & $\mathbf{\%}$ & $\mathbf{n}$ & $\mathbf{\%}$ & $\mathbf{n}$ & $\mathbf{\%}$ \\
\hline Data collection*** & 23 & 28.7 & 57 & 71.3 & 80 & 100 \\
Diagnosis* & 48 & 58.5 & 34 & 41.5 & 82 & 100 \\
Planning ** & 26 & 32.0 & 55 & 68.0 & 81 & 100 \\
Prescription * & 19 & 23.2 & 63 & 76.8 & 82 & 100 \\
Evolution * & 28 & 34.2 & 54 & 65.8 & 82 & 100 \\
\hline * one nurse did not respond & & & & & \\
** two nurses did not respond & & & & & \\
*** three nurses did not respond & & & & & \\
$\mathrm{n}=$ number of respondents & & & & &
\end{tabular}

Table 2 shows difficulties found by nurses in order to perform the components of each phase of the nursing process. For data collection, $53.2 \%$ of the answers were observed to relate difficulties in executing the interview, and $46.8 \%$ reported difficulties with the physical exam. Regarding the components of the nursing diagnosis, $39.3 \%$ reported difficulties in identifying the defining characteristics; $34.5 \%$ in establishing diagnostic characteristics; and $26.2 \%$ reported related factors. As for 
Table 2 - Components of the phases of the nursing process where the nurses find difficulties

\begin{tabular}{|c|c|c|c|c|c|c|c|c|}
\hline \multicolumn{9}{|c|}{ Phases of the Nursing Process } \\
\hline \multicolumn{3}{|c|}{$\begin{array}{c}\text { Data Collection } \\
\mathrm{N}=47\end{array}$} & \multicolumn{3}{|c|}{$\begin{array}{l}\text { Nursing Diagnosis } \\
\qquad \begin{array}{l}\mathbf{N}=58\end{array}\end{array}$} & \multicolumn{3}{|c|}{$\begin{array}{l}\text { Care Planning } \\
\quad \mathbf{N}=58\end{array}$} \\
\hline Components & n* & $\%$ & Components & n* & $\%$ & Components & $\mathbf{n}$ & $\%$ \\
\hline Interview & 33 & 53,2 & Defining characteristics & 33 & 39,3 & Definition of expected results & 41 & 70,7 \\
\hline Physical exam & 29 & 46,8 & Diagnostic Categories & 29 & 34,5 & Intervention proposals & 17 & 29,3 \\
\hline & & & Related factors & 12 & 26,2 & & & \\
\hline Total & 62 & 100,0 & Total & 84 & 100,0 & Total & 58 & 100,0 \\
\hline
\end{tabular}

$\mathrm{N}=$ number of respondents

$\mathrm{n}=$ number of responses

* non-mutually-excluding responses

Table 3 - Physical exam technique nurses reported as difficult to perform

\begin{tabular}{lrr}
\hline \multicolumn{1}{c}{ Physical exam technique } & \multicolumn{2}{c}{ Frequency } \\
\cline { 2 - 3 } & $\mathbf{N}=\mathbf{2 9}$ & $\mathbf{n}$ \\
\hline Auscultation & 16 & 39,0 \\
Percussion & 14 & 34,1 \\
Palpation & 7 & 17,1 \\
Inspection & 4 & 9,8 \\
\hline Total & $\mathbf{4 1}$ & $\mathbf{1 0 0 , 0}$ \\
\hline $\mathrm{N}=$ number of respondents & & \\
$\mathrm{n}=$ number of responses & & \\
$*$ non-mutually-excluding responses & &
\end{tabular}

care planning, $70.7 \%$ of the answers indicated difficulties in determining the expected results, and $29.3 \%$ in proposing intervention.

Considering the difficulties reported in the nurses' everyday practice when performing physical exams, the option of choice was to investigate the problems that they faced when performing the techniques employed in this activity, shown in Table 3. Forty-one answers were received from 29 respondents, with 39\% mentioning difficulties with auscultation, $34.1 \%$ with percussion, $17.1 \%$ with palpation, and $9.8 \%$ with inspection.

The Table 4 shows answers from nurses regarding the reasons they attribute to the difficulties found when executing each phase of the nursing process. The reasons presented for data collection were: "Lack of time" (43.5\%); "Patient's limitation to inform" $(21.7 \%)$; "Brochure used is inadequate", and "Lack of theoretical knowledge" (17.4\%). For nursing diagnosis: "Defining diagnostic characteristics" (51\%), "Lack of theoretical knowledge" (26.4\%), and "Lack of practical exercise" (15.1\%). For care planning: "Lack of theoretical knowledge" (36.3\%), "Lack of practical exercise" (31.8\%), and "Lack of time" $(9.1 \%)$. For nursing prescription: "Lack of theoretical knowledge" (47.0\%), "Lack of time" (17.6\%), "Lack of practical exercise", and "Lack of resources" $(11.8 \%)$. Finally, the reasons attributed to difficulties

Table 4 - Difficulties attributed by the nurses to execute the phases of the nursing process

\begin{tabular}{|c|c|c|c|c|c|c|c|c|c|c|}
\hline \multirow{3}{*}{ Reasons for difficulty } & \multicolumn{10}{|c|}{ Phases of the Nursing Process } \\
\hline & \multicolumn{2}{|c|}{$\begin{array}{c}\text { Data } \\
\text { Collection } \\
\mathrm{N}=19 \\
\end{array}$} & \multicolumn{2}{|c|}{$\begin{array}{c}\text { Nursing } \\
\text { Diagnosis } \\
\mathrm{N}=42\end{array}$} & \multicolumn{2}{|c|}{$\begin{array}{c}\text { Care } \\
\text { Planning } \\
\mathbf{N}=17\end{array}$} & \multicolumn{2}{|c|}{$\begin{array}{c}\text { Nursing } \\
\text { Prescription } \\
\mathrm{N}=14\end{array}$} & \multicolumn{2}{|c|}{$\begin{array}{c}\text { Nursing } \\
\text { Evolution } \\
\mathbf{N}=23\end{array}$} \\
\hline & n* & $\%$ & $\mathrm{n}^{*}$ & $\%$ & $\mathrm{n}^{*}$ & $\%$ & $\mathrm{n}^{*}$ & $\%$ & $\mathrm{n}^{*}$ & $\%$ \\
\hline Lack of time & 10 & 43.5 & - & - & 02 & 9,1 & 03 & 17,6 & 09 & 30,0 \\
\hline Lack of theoretical knowledge & 04 & 17.4 & 14 & 26,4 & 08 & 36,3 & 08 & 47,0 & 09 & 30,0 \\
\hline Lack of practical exercise & - & - & 08 & 15,1 & 07 & 31,8 & 02 & 11,8 & - & - \\
\hline Brochure in use is inadequate & 04 & 17.4 & - & - & - & - & - & - & - & 一 \\
\hline Patient's limitation to inform & 05 & 21.7 & - & - & - & - & - & 一 & - & 一 \\
\hline Defining diagnosis characteristics & - & - & 27 & 51,0 & - & - & - & 一 & - & 一 \\
\hline Lack of resources & - & - & - & - & - & - & 02 & 11,8 & - & - \\
\hline Medical records unavailable & - & - & - & - & - & - & - & - & 03 & 10,0 \\
\hline $\begin{array}{l}\text { Not being able to follow patient's } \\
\text { evolution on a daily basis }\end{array}$ & - & - & - & - & - & 一 & - & - & 02 & 6,7 \\
\hline $\begin{array}{l}\text { Not performing the other phases } \\
\text { of the nursing process }\end{array}$ & - & - & - & - & - & - & - & - & 02 & 6,7 \\
\hline Not enough staff in the unit & - & - & - & - & - & - & - & - & 02 & 6,7 \\
\hline Other reasons & - & - & 04 & 7,5 & 05 & 22,8 & 02 & 11,8 & 03 & 10,0 \\
\hline Total & 23 & 100,0 & 53 & 100,0 & 22 & 100,0 & 17 & 100,0 & 30 & 100,0 \\
\hline
\end{tabular}


Table 5 - Easy aspects in executing the phases of the nursing process, as reported by nurses

\begin{tabular}{|c|c|c|c|c|c|c|c|c|c|c|}
\hline \multirow{3}{*}{ Reasons for the easy aspects } & \multicolumn{10}{|c|}{ Phases of the nursing process } \\
\hline & \multicolumn{2}{|c|}{$\begin{array}{c}\text { Data } \\
\text { Collection } \\
N=31\end{array}$} & \multicolumn{2}{|c|}{$\begin{array}{c}\text { Nursing } \\
\text { Diagnosis } \\
\mathbf{N}=10\end{array}$} & \multicolumn{2}{|c|}{$\begin{array}{c}\text { Care } \\
\text { Planning } \\
\mathbf{N}=24\end{array}$} & \multicolumn{2}{|c|}{$\begin{array}{c}\text { Nursing } \\
\text { Prescription } \\
\mathbf{N}=32\end{array}$} & \multicolumn{2}{|c|}{$\begin{array}{c}\text { Nursing } \\
\text { Evolution } \\
\mathbf{N}=16\end{array}$} \\
\hline & $\mathrm{n}^{*}$ & $\%$ & $\mathrm{n}^{*}$ & $\%$ & n* & $\%$ & $\mathrm{n}^{*}$ & $\%$ & $\mathrm{n}^{*}$ & $\%$ \\
\hline $\begin{array}{l}\text { Has theoretical knowledge and practical } \\
\text { experience }\end{array}$ & - & - & 06 & 60,0 & 08 & 33,4 & 14 & 41,2 & 08 & 47,1 \\
\hline $\begin{array}{l}\text { Received theoretical-practical training in the } \\
\text { hospital }\end{array}$ & 05 & 14,4 & - & - & 02 & 8,3 & 03 & 8,8 & 03 & 17,6 \\
\hline Learned and executed the phase during graduation & 06 & 17,1 & - & - & 02 & 8,3 & 02 & 5,9 & 02 & 11,8 \\
\hline $\begin{array}{l}\text { Performed the previous phases of the Nursing } \\
\text { Process }\end{array}$ & - & - & - & - & 07 & 29,2 & 13 & 38,2 & 01 & 5,9 \\
\hline Finds it easy to communicate & 06 & 17,1 & - & - & - & - & - & - & - & - \\
\hline $\begin{array}{l}\text { It is the quickest and most objective phase of the } \\
\text { nursing process }\end{array}$ & 06 & 17,1 & - & - & - & - & - & - & - & - \\
\hline Uses books as reference sources & - & - & 03 & 30,0 & 03 & 12,5 & - & - & - & - \\
\hline Has enough time for performing the phase & - & - & 01 & 10,0 & - & - & - & - & - & - \\
\hline $\begin{array}{l}\text { Has brochures directed and adequate to the } \\
\text { service in the unit }\end{array}$ & 08 & 22,9 & - & - & - & - & - & - & - & - \\
\hline Other facilitators & 04 & 11,4 & - & - & 02 & 8,3 & 02 & 5,9 & 03 & 17,6 \\
\hline Total & 35 & 100,0 & 10 & 100,0 & 24 & 100,0 & 34 & 100,0 & 17 & 100,0 \\
\hline
\end{tabular}

$\mathrm{N}=$ number of respondents

$\mathrm{n}=$ number of responses

* non-mutually-excluding responses

in nursing evolution were: "Lack of knowledge" and "Lack of time" (30\% each), "Medical records unavailable" (10.0\%), "Not being able to follow patient's evolution daily", "Not performing the other phases of the nursing process", and "Not enough staff in the unit" (6.7\% each).

Table 5 shows easy aspects reported by the nurses for the execution of each phase of the nursing process, among them: "Having theoretical knowledge and practical experience" to execute diagnosis $(60 \%)$, evolution (47.1\%), prescription (41.2\%) and assistance planning (33.4\%); "Having received theoreticalpractical training at the hospital", for the execution of the phases: evolution $(17.6 \%)$, data collection $(14.4 \%)$, prescription $(8.8 \%)$ and planning $(8.3 \%)$; "Having learned and executed the phase during graduation", related to the phases: data collection $(17.1 \%)$, evolution $(11.8 \%)$, planning $(8.3 \%)$ and prescription (5.9\%); "Having performed the previous phases of the nursing process", for the execution of the phases: prescription $(38.2 \%)$, planning $(29.2 \%)$ and nursing evolution (5.9\%); "Using books as reference sources" for the phases: diagnostics (30\%) and planning (12.5\%); "Being communicative" and "Being the fastest and most objective phase of the nursing process" were quoted as being easy aspects to execute data collection (17.1\%); "Having a brochure that is suitable for the service" was also considered an easy aspect of data collection (22.9\%), and "having enough time for the execution" was quoted when dealing with nursing diagnosis $(10 \%)$.

\section{DISCUSSION}

Phases of the nursing process in which nurses find difficulties and reasons why that happens

The data presented in Table 1 show that the phase considered the most difficult by nurses is diagnosis, followed by the phases of evolution and care planning, which are similar to results found in other studies ${ }^{(1,4)}$.

The most important cause of difficulty reported for nursing diagnosis (Table 4) was having insufficient basic and specific theoretical knowledge about diagnostic taxonomy for practical applications. The nurses stated that this was due to "not having learned and not knowing how to do it or how to interpret it".

Reports also showed that the nursing diagnosis reasoning depended on medical diagnosis (biomedical reasoning). Nurses stated that the difficulty in determining the nursing diagnosis happens because these were dependent on the disease, and doubts increased even more when the physician marked the patient's diagnosis with a question mark. It should also be mentioned that the patient's problems, when approached by the nurse, are different from those approached by the physician, although the methods used for their identification and the use of diagnostic categories are similar ${ }^{(5)}$.

Table 2 shows that nurses considered every diagnosis phase as being difficult to perform. In order to identify the defining characteristics, the difficulties were linked to the cognitive demands for the capacity of grouping the data collected and relate them with the client's health problems. Nurses also considered that determining the 
diagnosis categories, also highlighted as a difficult stage when establishing the nursing diagnosis in another study ${ }^{(6)}$, was a difficult task. The difficulties involved refer to insufficient theoretical background, human and biological sciences, added to a lack of knowledge in Semiology (necessary to perform physical exam techniques - inspection, palpation, percussion and auscultation, as shown on Table 3) to collect and interpret relevant data. Furthermore, regarding the identification of related factors, difficulties are linked to the necessary degree of knowledge for observing behavior changes or normal manifestations (standard), and relate the inference defined from the data collected.

Other authors also mention nursing evolution as being a problem ${ }^{(7-8)}$. This refers to the second phase where difficulties were pointed out when the nursing process is executed (Table 1). According to one of them ${ }^{(8)}$, the nurses consider evolution difficult because it demands in-depth technical-scientific knowledge, reasoning, and constant updating on physiopathology.

Lack of knowledge, mentioned in Table 4 as a complicating factor when performing evolution, is related to specific knowledge of the evolution content (what to evolve and how to evolve). These doubts reflect the nurses' insufficient knowledge when facing the meaning and objective of nursing evolution, not associating this phase with the need of critical reflection to focus on analyzing the client's responses and development in relation to the proposed therapy.

Care planning, mentioned as a source of difficulty for $32.0 \%$ of the nurses (Table 1), is the final product of the act of planning care, and it is observed as not being very commonly used in SNC practices. At this point, the problem (diagnosis), the goals (expected results) and specific actions to be performed (proposed interventions) should be present.

Table 2 shows that the determination of expected results, similar to the findings of another study ${ }^{(6)}$, was considered the most difficult component when performing care planning. Table 4 shows that the difficulties in this phase are related to "lack of theoretical knowledge" and "lack of practical exercise". These were the explanations presented for the fact that the component phases of care planning are not registered, under the allegation of not being able to perform this phase due to "lack of knowledge and better understanding". Furthermore, nurses consider it "very complicated", or "not part of the everyday routine".

Regarding nursing prescription, where fewer nurses $(23.2 \%)$ reported difficulties (Table 1$)$, literature presents different perspectives. One of the studies shows similar results ${ }^{(4)}$, while others point this phase as the most difficult ${ }^{(2)}$, the most important ${ }^{(8)}$, and the most commonly used to teach the nursing process in nursing schools $^{(9)}$. Lack of theoretical knowledge and lack of practical exercise, mentioned as complicating factors in Table 4 were attributed to insufficient scientific knowledge needed to prescribe adequate activities. Many times, for fear of assuming a nursing behavior and its consequences, the nurses adopt the easier way of letting the physician make the decisions ${ }^{(10)}$.

Finally, results regarding data collection (Table 1) show that only 23 nurses $(28.7 \%)$ reported difficulties. These results have no logic correspondence with the answers presented in Table 2, where twice as many nurses $(47 ; 56.6 \%)$ mentioned having difficulties with the interview or the physical exam. They report difficulties regarding the techniques that make up this phase, with the highest difficulty being to carry out the interview. Divergence among the responses presented allows for the inference that the nurses may be unaware of the components of each of the nursing process phases. The difficulties faced when performing the physical exam are also shown in other studies ${ }^{(1,3-4)}$. One of these concluded that the nurses performed the physical exam incompletely, focusing only the system affected by the disease $^{(4)}$. The second study observes that, although SNC has been implemented for almost 20 years in the hospital studied, nearly half the interviewed nurses said they had difficulties with the physical exam ${ }^{(1)}$. The third study reports that one of the obstacles to the implementation of the nursing process in a university hospital was the nurses' difficulty to perform the physical exam, especially lung and heart auscultation, as well as percussion and palpation ${ }^{(3)}$. Table 3 presents a similar finding to this last study, revealing that the most difficult aspect of the physical exam was the technique of auscultation, followed by percussion. Inspection was the method of lowest difficulty, followed by palpation.

Table 4 highlights "lack of time" as the most commonly mentioned hindrance to perform data collection (43.5\%). A similar result was found by Farias $^{(1)}$, when concluding that the nurses did not fill out the nursing history form (data collection) due to lack of time. Although the time necessary to execute each phase of the process is known, particularly data collection, the fundamental importance of this phase should be considered, since it constitutes the assessment reference that allows for the unfolding (and efficiency) of all subsequent stages, and for being configured as the nurse's exclusive responsibility, which must not be delegated.

Easy aspects in executing the phases of the nursing process

It can be observed in Table 5 that about half the answers pointing to the easy aspects of performing the 
diagnosis, care planning, prescription and evolution phases are predominantly related to knowledge. According to the nurses' reports, the theoretical and practical background acquired during their undergraduate course; the fact of having been executing the nursing process since they graduated and in their everyday routines; having been specifically trained for each phase; and having specific knowledge about physiopathology and the SNC itself are considered facilitators. These perceptions are encouraging. They reflect that these professionals are aware of the need to obtain specific knowledge to execute the phases of the nursing process. They also show beliefs and values that methodology use is scientifically supported on knowledge, as opposed to automatically executing the phases like bureaucratic routines and documental registration, observed in the daily practice of many nurses in health institutions.

Another relevant aspect observed in the received answers was the emphasis on the opportunity of having had practical experience of the knowledge acquired. This corroborates the fact highlighted by Carvalho ${ }^{(11)}$, when citing that, in the percentile chart of mnemonic retention, students retain $90 \%$ of what is taught when they listen and promptly perform the instructions they received.

In this context, it can be stated that the challenge of being in real, dynamic situations is a strong encouragement for learning. The importance of experience in decision-making is emphasized, because the breadth and the extension of knowledge of the experts, obtained from opportunities to apply theory to real situations, greatly stresses the capacity of critical thinking ${ }^{(12)}$.

"Having performed or executed the previous stages of the phase of the nursing process" was also mentioned in some answers as a facility for the completion of planning, prescription and evolution. These answers suggest the perception they have of the nursing process as a sequence of interrelated and interdependent actions. They demonstrate understanding about why the execution is dependent on the previous phases for the understanding, diagnosis and execution of the later phases. This process is called critical reasoning ${ }^{(13)}$.

"Using the book as a reference source" was mentioned as a facilitator to perform diagnosis and care planning. Using books as reference sources reflects the importance placed in reading for seeking and to complement knowledge, as well as to obtain answers to the problems found. People turn to reading whenever they start to organize their acquired knowledge, from situations brought up front by reality and how people act when faced with these situations; when they start to establish relationships between experiences and try to solve the problems that come up ${ }^{(14)}$.

\section{CONCLUSIONS AND IMPLICATIONS FOR THE NURSING PRACTICE}

The center of the easy aspects reported by the nurses for executing the phases of the nursing process is generally associated with the theoretical and practical knowledge needed. Once again, this convergence highlights the importance and value that the nurses assign to adequate and necessary scientific knowledge, as a basis for decision-making when choosing interventions to provide patient care, subsidizing clinical and critical reasoning in nursing.

Lack of sufficient knowledge about the nursing process becomes a barrier for the nurses' compliance to its execution in healthcare institutions. When performed without the necessary knowledge, it is simply done as the completion of an institutional task, without the collective awareness of how important this process is for the nurses' development as health professionals with social responsibilities.

Another aspect to be observed is that, although most nurses reported having learned and executed the phases of the process during their undergraduate courses, the difficulties were expressive, showing the insufficiency of the theoretical and practical preparation of the nurse for the systematization of nursing care after they finish their graduate courses.

Thus, the importance of reflecting on the curriculum and the thematic content offered in the nursing schools is highlighted, since these should prioritize the verticalization of knowledge, enabling a more in-depth approach, as opposed to horizontal teaching, where the student acquires superficial and insufficient knowledge for the practice of the nursing process. This need becomes more urgent when the difficulties found by the nurses when performing the process, reported in this study and others, are evidenced by gaps in nursing teaching, since, not being approached during the academic training, reverberate as difficulties and noncompliance to the execution of the nursing process in the professional life.

Yet another aspect to be considered is the revision of training according to the biomedical model, still performed by many professors in nursing undergraduate courses, emphasizing the affected biological structure, i.e., the disease. This perspective is inadequate to the nursing outlook. It is necessary to consider the whole individual and diagnose the affected needs.

From this context, the reevaluation of the theoretical education of the nursing process is suggested, as well as the re-structuring of the practical activities in the undergraduate courses. Furthermore, the following strategies are suggested in order to improve the quality of education and professional practice of the nurses: residence 
in nursing for all students who conclude graduation, as a practical exercise of clinical and critical reasoning in nursing in service training conditions; continuing education, as an alternative for the improvement of knowledge, with updating courses; and the renewal of the professional license by the class entity, linked to the attestation of updating courses taking during the year.

In conclusion, the findings in this study answer the initial questions of the research, and the execution of the phases of the nursing process and its continuous maintenance, natural to the professional exercise, is linked to these professionals' capacity of executing such activities, and the awareness of their importance for the profession.

Finally, it should be added that there are other reasons mentioned in several studies as hindrances for the execution of the nursing process, as well as infra-

\section{REFERENCES}

1. Farias FAC. Sistematização da assistência de enfermagem: como enfermeiros percebem o histórico e o diagnóstico [tese]. São Paulo: Escola de Enfermagem da Universidade de São Paulo; 1997.

2. Campedelli MC, Gaidzinski RR. A metodologia assistencial de enfermagem na prática: Hospital Universitário da USP. Rev Esc Enferm USP. 1987; 21(N Esp):62-7.

3. Barros ALBL. O trabalho docente assistencial de enfermagem no hospital São Paulo da UNIFESP/EPM [tese]. São Paulo: Universidade Federal de São Paulo. Escola Paulista de Medicina; 1998.

4. Thomaz VA, Guidardello EB. Sistematização da assistência de enfermagem: problemas identificados pelos enfermeiros. Nursing (São Paulo). 2002; 5(54):28-34.

5. Kron T, Gray A. Administração dos cuidados de enfermagem ao paciente: colocando em ação as habilidades de liderança. Rio de Janeiro: Interlivros; 1994.

6. Gonçalves R, Narchi NZ. Avaliação do ensino teórico e prático do processo de enfermagem. Rev Paul Enferm. 2001; 20(3):4-67.

7. Horr L, Gonçalves LHT, Saupe R. O ensino da metodologia structural issues related to: physical plant, insufficient personnel, lack of time, excessive attributions of the nurse, lack of leadership abilities by the supervision when overseeing this activity, lack of administrative support, lack of material resources, among others. The nurses' lack of knowledge to perform the process is the main reason leading these professionals to avoid executing it in their day-to-day routines. Consequently, they are unaware of the importance of their agreement and involvement with the methodology of care for the systematization of nursing care. This leads them to doubt, and therefore not comply with the nursing process. In turn, they do not get the social recognition of their profession from society, when they do not link their professional activity to the object of their profession: healthcare planning.

assistencial de enfermagem: Departamento de Enfermagem - UFSC. Rev Esc Enferm USP. 1987; 21(N Esp):40-54.

8. Utyama IKA, Uratani M. O ensino do processo de enfermagem: opinião dos enfermeiros. Rev Bras Enferm. 1990; 43(1/4):19-25.

9. Dell'Acqua MCQ. Ensino do processo de enfermagem nas escolas de graduação em enfermagem do Estado de São Paulo [tese]. São Paulo: Escola de Enfermagem da Universidade de São Paulo; 1999.

10. Maria VLR, Dias AMC, Shiotsu CH, Farias FAC. Sistematização da assistência de enfermagem no Instituto Dante Pazzanese de Cardiologia: relato de experiência. Rev Esc Enferm USP. 1987; 21(N Esp):77-87.

11. Carvalho AV. Treinamento de recursos humanos. São Paulo: Pioneira; 1988.

12. Alfaro-LeFevre R. Pensamento crítico em enfermagem: um enfoque prático. Porto Alegre: Artes Médicas; 1996.

13. Potter PA, Perry AG. Fundamentos de enfermagem: conceitos, processo e prática. 4a. ed. Rio Janeiro: Guanabara Koogan; 1999. p.91-189.

14. Martins MH. O que é leitura. 19a ed. São Paulo: Brasiliense; 1994. 